DOI 10.1515/linpo-2017-0007

\title{
Philosophical dialogue - towards the cultural history of the genre
}

\author{
Marta Rakoczy
}

Institute of Polish Culture, University of Warsaw

marta.rakoczy@wp.pl

\begin{abstract}
Marta Rakoczy. Philosophical dialogue - towards the cultural history of the genre. The Poznań Society for the Advancement of the Arts and Sciences, PL ISSN 0079-4740, pp. 79-93

This text analyzes philosophical dialogue (from Plato to Augustine of Hippo, Berkeley, Hume and Leibniz) as a linguistic genre embedded in the cultural, historical and media context, which was decisive for the role and functions accorded to philosophy as such. I argue that one way to describe transformations of Western thought, which has not been consistently implemented, is a description of its history through the category of progressive textualization and through anthropological-historical category of a genre. Two models of communication analyzed by Ives Winkin - orchestral and telegraphic - first associated with the perception of communication as an act of interpersonal, linguistic and non-linguistic communio, and second, the perception of communication as a linear transfer of information from one mind to another, have their historical, especially the media roots. The first is associated with the word alive and spoken communication. The second is conditioned by the primacy of the printed word and the quiet, solitary reading, which cuts off existential contexts, and decontextualizes an utterance and tranforms it into a strictly graphic message far from direct, interpersonal understanding. Both models can be seen well in philosophical texts. And the dominance of the latter, related to the development of print culture, allows us to understand why the philosophical dialogue as a trace of the conversation - a trace of the existential practice as well as philosophical - is experiencing a crisis in modern times.
\end{abstract}

Keywords: philosophical dialogue, communication, linguistic genre, linguistic practice, cultural practice, anthropology of word

\section{Defining the problem a philosophical dialogue as genre}

In this article, the philosophical dialogue as a textual genre is discussed, from the perspective which is based on the anthropology of the word and communicology (Godlewski et al. 2003; Wendland 2015). This means that at the starting point I will primarily consider the very form of the genre, not the content being expressed. This form will be analyzed, however, in a specific manner, the one which is distant from the classic philological tools: the form will not be accounted for literary expression skills of the 
representatives of this genre. It will primarily be the evidence of the linguistic practices characteristic of philosophy understood as a historically variable cultural institution, especially the transformation of media, which have had an impact on these practices, and hence on the way philosophy being practiced. This does not mean that while studying the form of dialogue as involved in specific cultural circumstances their content is underestimated. On the contrary, the study of specific linguistic genres and practices that are included in the background of various, not only philosophical, texts, is to be treated as unavoidable. This study seems necessary not only because we aim at comprehending their content, but also, to put it more broadly, in order to grasp their cultural function. The meaning of a text is not, in fact, constituted by its own discourse, but by the complex cultural background which the discourse consists of. In other words, I will treat here the genres used in philosophical discourse as genres closely related to socially and culturally shaped social practices, thus as related to culture as such.

Focusing on the genre of dialogue as a medium carrying specific, often overlooked by historians of philosophy, meaning, I aim at underscoring that its form had not only a certain, formed by practice, origin, but also that it had practical consequences, which are decisive in regard to the ways philosophy was understood and practiced. Each text, in fact, if it is not considered as an autonomous discourse - not as a meaningful one by the virtue of its language organisation, but by the virtue of its cultural communicative context in which it operates - is originated by something more than the author as a representative of specific ideas and specific writing technique. Texts have to be seen, above all, against their rich cultural background, whose individual components have to be analyzed historically and anthropologically in order to understand their message.

The perspective which is being put forward here has had, of course, a long history, the beginning of which is associated primarily with Mikhail Bakhtin and his concept of literature, the concept according to which literature has to be seen in the perspective of speech genres, from which it emerges and which it converts. Taking into account the relationships between literature and language practices as different forms of communication allows to see both its artistry and the ingenuity of the cultural background from which it draws its potential (Bakhtin 1986). For example, according to Bakhtin, any understanding of the works of Rabelais is impossible without understanding of the medieval folk culture, fair and carnival culture as culturally legitimized forms of undermining, discrediting and converting sacred values - the culture which sophisticated forms of oral expression were directed against the official discourse constituting superiority of spirit over body culture (Bakhtin: 1968). The perspective being put forward here has had yet another inspiration, namely, last project of Michel Foucalt, who in lectures designed for the College de France in 1981-1982 tried to look at the history of philosophy by following a collection of incredibly rich and dense concepts, practices, ways of being, forms of existence which emerged from classical texts (Foucault 2005). Although, of course, in the Foucault's project the categories of language, media and communication do not constitute the most important analytical tools.

It was the developed culture of printing, as was claimed afterwards by Walter J. Ong, that taught us to think of a literary, scientific or philosophical text as of an autonomous discourse, which is a work of an outstanding individual, separated from the linguistic 
context of culture, age, language environment, which have brought it to life (Ong 1982). However, genres of speech, as well as literary genres, including texts, are results of the historically specified actions, and as such draw their thematic organization from the interaction between systems of social values, language conventions, and the presented world (Bauman 1986; Hanks 1987; Bauman \& Briggs 1992). Language genres "derive their practical reality from specific acts of language, which originate and which they are products of' (Hanks 1987).

The same is true for the genres present in philosophy. To comprehend them as forms of communication which constitute the history of philosophy is necessary in order to understand philosophy itself. The choice of dialogue or treatise as the form of expression of philosophical content is not an arbitrary choice of poetics or of the style of presentation of certain content for which the form is essentially irrelevant (Rakoczy 2014). It is a choice conditioned, though not entirely, by specific cultural and media mechanisms. These mechanisms are crucial to the shape of the practice of philosophy and its role in individual life, and social and political life as well. That is why the central question of this article is a question of cultural and media background, on the basis of which such a genre as philosophical dialogue was formed, firstly invented and then gradually abandoned in the modern era, and the question of what were the cultural reasons for this abandonment.

\subsection{The dialectics as a conversation - Socrates}

Plato's Phaedrus starts with the famous walk of Socrates and his disciple, during which the trees outside the city walls, the "delightful", "so sweet" breeze, "chorus of cicadae", grass "like a pillow gently sloping to the head" make the philosopher feel genuine delight (Plato 1997: 510). Nature experienced there has not yet anything to do with the modern category of nature, is not yet a subject to clearly separated from each other types of experience: cognitive, aesthetic and ethical, whose individuality will be confirmed by characteristic for the modern philosophy separation of aesthetics, epistemology and ethics, diagnosed and criticized by such philosophers as, on the one hand, Heidegger and Gadamer, on the other Horkheimer and Adorno. Nature in the indicated passage was not yet viewed and contemplated as a purely aesthetically recognized "view" or "landscape" that would be, according to Joachim Ritter, an invention of Petrarch. The text clearly indicates that in the times of Socrates one goes out of town because it is more convenient to pass along there than through winding streets: there is a stream, where one can cool off, the trees, in whose shade one can relax and grass to lie down on. The experience of the philosopher and the disciple is, however, multi-faceted: nature here is not only a source of physical pleasure and rest, because their conversation goes on for a while around where in the stream Boreas kidnapped Orithyia (509). Although Socrates believes such investigation to be a waste of time, he does not deny the obviousness of such associations. Ilissos flowing near the city also associates the story of the nymphs and the god of the north wind. Places evoke stories, because the experience of nature is also an experience of myth, whether one believes it is true. 
To Phaedrus, Socrates' delight seems strange: it strikes him as a foreigner's account. Probably a story of one's own enchantment caused by nature in the suburbs is also not a topic of a daily conversation of contemporary Greeks. Phaedrus' remark that Socrates never leaves the city, provokes the famous retort: "Landscapes and trees have nothing to teach me, only the people in the city can do that" (Plato 1997: 510) The source of the philosophy of Socrates is conversation: one can listen to the wind, but one can not practice dialectics with them. The specificity of this concept of philosophy can be seen more clearly if it is contrasted with a completely different, modern this time, excerpt in which Descartes, wanting to give positive expression of his commitment to and progress of philosophy, says that after years of travelling and meditation he learned to treat people he encountered as indifferently as trees passed by in the woods. Neither nature nor people mean anything to the philosopher, they are only a backdrop for lonely thoughts. Each of them not so much does not want to teach as can not teach. A threat for philosophical investigations is posed especially by friends and social life. Settling in Amsterdam, where everyone minds their own business or trade, is a blessing for Descartes because here he has "been enabled to live without being deprived of any of the conveniences to be had in the most populous cities, and yet as solitary and as retired as in the midst of the most remote deserts" (Descartes 2009). We are at the antipodes of Plato's concept, according to which friendship, just as philosophy, is political in nature, and in which a community of people talking to each other, especially a community of friends, is the beginning, not the end of thinking (Arendt 2005: 17-18). Expressed by Hannah Arendt's view that 'thinking, although it is always done in words, not requires an audience, which is why Hegel, according to the evidence provided by lives of almost all philosophers, used to say that "philosophy is a matter of solitude" (Arendt 1977), is an outcome of the modern times, the development of printing and the fall of the language practices the ancient philosophy was based on.

This is why Cassirer claimed in Essay on Man that the truth in Socrates' and Plato's approach as well can only be achieved by continually interacting minds in mutual questions and answers (Cassirer 1972). And yet Cassirer was wrong about two issues. Firstly, he defines Socrates' dialectics as a "synergy of minds", projecting into it the mode of thinking characteristic of modern philosophy, for which the mind, and not the person in its socio-political environment is the subject of philosophy: this thinking is behind all modern forms of understanding of dialectics as a method of individual, correct thinking or reasoning, not as a method of collective, performed between people, activity. Secondly, Cassirer examines Plato's and Socrates' dialectics as an independent intellectual invention of the philosophers, whereas - as Arendt remarks - both philosophers made a part of the moment of decline of a cultural formation, which was decisive in terms of their political and intellectual activity. The cultural formation, which consisted of - as I claim - among other things, certain linguistic practices. We do not have, of course, direct access to them: all of what a historian of both culture and philosophy is able to get hold of are their outcomes, which have undergone deeply transformation caused by the use of the medium of writing. Yet those practices, as well as the types of speech that ruled them, find their distant reflection in the texts. A good example of this is the Apology of Socrates. The awareness of the failure of the defense strategy adopted by Socrates lies in choosing 
a different kind of speech than the one awaited by his audience. Plato's master performs conversation according to the rules of dialectics, not delivering a speech prepared according to the rules of the art of rhetoric, proper for a court hearing. The very linguistic practice proves his resistance and prejudges the outcome of the process. It is these two practices and at the same time speech genres that will be the hotbed of Plato's contempt for rhetoric and his formulating of the opposition between knowledge and opinion, or - according to Arendt - between a conversation as truly political practice and persuasion as a practice of apolitical, although still verbal, non-physical violence.

\subsection{Dialectics as a trace of the conversation - Plato and the beginnings of textualization}

Plato's choosing of a philosophical dialogue as a textual form is clearly isomorphic to his concept of philosophy. Dialogue is to manifest truth, which is not included in the sentence, assertion, but somehow emerges, often unspoken, from dialectical agon: as Arendt wrote, "this kind of dialogue, which doesn't need a conclusion in order to be meaningful" (Arendt 2005: 16) In this sense, there is no contradiction between the famous Seventh Epistle saying of the ultimate inexpressibility of the philosophical experience, and his other writings. The place of proper disclosure of truth is a conversation between concrete people engaged in joint thinking, more precisely - people who share the bonds of friendship based on choosing of similar goals and values. Those do not need conclusions to grasp the meaningfulness of the conversation. Furthermore, lack of conclusion is often a guarantee of its success. Precisely because of this, among other things, in the philosophy of Plato, a noticeable tension emerges between the exoteric and the esoteric tradition: between a living, oral conversation and what has been written down and which is only a closed testimony of a living dialogue. This tension is, at the same time, a tension between what is done and created in a group of friends of Socrates or pupils of Plato's academy, people close to each other primarily through joint discussions, and what is suitable for a wider, and largely anonymous for themselves audience, who reads Plato's texts. The thought is, in this perspective is not so much, to secondary to the words, as to conversation. The latter is neither an exchange of information nor a social ritual consisting in confirming the common world of meanings and values. It is an existential practice consisting of, undertaken with a common purpose, lively exchange of ideas and experiences aimed at transforming them. This means that truth is not of language nature, and even more: it can not be deposited in the textual discourse understood as an autonomous discourse, independent from the practice of philosophical life.

It is no coincidence that both Plato and Aristotle use for their philosophical diagnoses the notion of theoria. This term in Greek originally meant practice. Theoros is a person who sets out on a journey beyond the polis, to experience hierophant in a holy place, and then comes back and recounts their experience (Nightingale 2004). This way of thinking can be clearly seen in the metaphor of a philosopher returning from the solar world of ideas to the cave in order to tell about the world that can not be understood in it. The function of the dialogue is not the description of truth, but a summon to the 
philosophical life. Plato and is neither a mystic nor irrationalist who is in favour of the ultimate inexpressibility of truth. Such interpretations belong to the sort of philosophical presentism which is dictated by the conviction that rationalism means seeking the truth of sentences or judgments placed in philosophical texts and referenced to reality as such. The belief is, according to Roy Harris, has a strong media base (Harris 2009). It is in the culture of advanced literacy, which is actually achieved only in the culture of print, text understood as a set of sentences separated from its author and the context of its expression, begins to be treated as a reference tool.

We do not know what linguistic and social practices formed the basis of the dialectical method, which was moved by Plato to the philosophical dialogue, and that ignorance makes historians write about its beginnings as of the so-called "Greek miracle". We do not know what role should be attributed, in terms of its founding, to writing either. If Aristotle is right in claiming that this method was invented Zeno of Elea in the fifth century $\mathrm{BC}$, then we deal with an invention which has been made at the times when reading and writing was a part of the systematic education of Athenian citizens. In the dialectical method, which uses a variety of logical techniques, one can find a lot of elements that literacy theorists associate with writing as such. Its aim is not so much a victory of one of the persons involved in the discussion as the search for truth: the aims of what is spoken are not only common, but also super-individual, universal. The scheme of the dialectical discussion inherited from Zeno, according to William K.C. Guthrie, was as follows: a questioner asked a question in the form of alternatives, which contained an insoluble, at the starting point, contradiction (1971). The interlocutor resolved it with a thesis, which was then challenged by the questioner. This discussion was therefore of a negative character, as well as later discussions of Socrates. It showed the insufficiency of responses, thus locating them outside of the context of the conversation, not achieved in the end.

The dialectic of Socrates, according to many researchers, shows a clear trait of literacy, because Socrates during a conversation is seeking a good definition, assuming, therefore, ontological independence of language, which can deceive us, especially in its everyday form. If Walter Ong and David R. Olson are right, when claim that separate words de-contextualised from their use are not subjected to analysis in oral cultures, because a word acts in those as part of a particular utterance, which belongs to a particular person, practice, genre, place and time, then Socrates' effort requires the awareness initiated by writing. On the other hand, this is the only half complete answer. Socrates does leave any writings, deciding on the oral philosophical activity consistently. He derives, as Guthrie mentions, the word dielegesthai (discussion) from the verb which means "to gather in order to discuss".

Philosophical investigation as the search for wisdom, virtue, and one's own "self" requires, in his view, frequent conversations with people having different life experiences. Socrates puts a clear emphasis on this in his apology, highlighting various professions and different social and political status of people who he accosts. They do not carry any views and beliefs, which could be contained in theses or statements deposited in texts. They are living persons having a particular social, moral, political constitution, and certain life experiences. Philosophical action, if it is to be politically and intellectually right, 
has to be based on this diversity, because the latter is a guarantee of the reliability of philosophy as something that must concern "common world" and the "common good". This is why, in her essay which was a tribute to Socrates, Arendt wrote that "political philosophy like all its other branches, will never be able to deny its origin in thaumadzein, in the wonder at that which is as it is. If philosophers, despite their necessary estrangement from the everyday life of human affairs, were ever to arrive at a true political philosophy, they would have to make the plurality of man, out of which arises the whole realm of human affairs - in its grandeur and misery - the object of their thaumadzein" (Arendt 2005: 38).

Philosophy as a conversation is a practice, but this is not only about what Pierre Hadot described as a spiritual exercise (Hadot 1995). It has a political nature, which is why Socrates emphasizes in his apology not so much that his activity is a value in itself, but that it is important for the polis. His accusers agree with him on one thing: the value of philosophy as paideia is determined by practice, with which the former results. This is why Socrates's pupils like Alcibiades and Kritias become the crowning argument against him and why Socrates in his speech is not able to fight off this accusation: his silence does not seem to be caused only by the amnesty, which participants for the disgraceful, for Athenian democracy, events, were provided with.

Plato takes this way of thinking to the text, changing it irrevocably. By creating a dialogue as a text genre Plato preserves and testifies a conversation, giving it a final and eventual, because of literate form. Therefore, early Platonic dialogues are a largely good source for understanding the historical Socrates, on the other hand, constitute a step towards a completely different philosophical practice. For persons taking part in a conversation which is transferred and transformed into a literary genre become characters of the text, and thus, to a greater extent, they represent not so many persons as certain beliefs and arguments that they support. They become a part of the literary world: Plato, as is known, was an extremely talented writer, which attaches a great significance to the form of a text, which is certainly not a true reflection of conversations that have been made. As to later dialogues, a text is just a failed projection, not a reminiscence of a conversation. In Politeia and the Nomoi, it becomes, de facto, scored for voices, Socrates's lecture, whom Plato makes an advocate of his theory of ideas, a theory, all historical sources say the same, can not be attributed the historical Socrates.

Plato's attitude towards writing and orality is ambivalent, which manifests itself, on one hand, in his dislike for poets, on the other for writing as a medium that makes more difficult, in his view, the search for wisdom (Havelock). Regardless of Eric Havelock's diagnoses concerning literary roots of Platonic metaphysics as based on viewed, silent ideas, the author of The Republic is a representative of the generation for whom writing as a medium is still a vivid problem, when it comes to the opportunities and threats it poses. This is reflected in his dialogues, which are not simply texts which imitate, for purely stylistic reasons, a conversation. Firstly Plato never creates fictional characters: the characters of his text are always historical persons, even if such philosophers used in Plato's later texts as Parmenides, could not be the interlocutors of Socrates. Theses are closely interwoven with persons and existential practice those persons represent, they are not autonomous, purely discursive beings. A dialogue is testified by lives of concrete, 
real persons, while the interpretation of the whole is influenced by extra-textual cultural authority, which each of the mentioned persons has.

World of dialogue also is not subject to discursive autonomization. Little is known about where and under what circumstances the presented people make conversations. Plato creates the world depicted as a playwright who leaves only very basic stage directions. Therefore, he makes no attempt to create a more or less independent world, a world which the reader could enter by means of his own imagination. On the contrary, he puts the reader in the middle of an ongoing conversation: we know little about its scenery, events preceding it, nor do we have any clues about how this work should be interpreted. In this sense, it is not an "autonomous discourse", written with the consideration of author's intentions and the interpretation of a reader, which can be divergent and whose divergence would be better avoided. The similarity of the dialogue to the drama is also significant even if we invoke the specific nature of the classical Greek drama.

The Greek word drama originally meant action, 'communication through action' (Morawski 2014) while drama itself was a multi-media spectacle. The Greek tragedians of the classical age were seen as the authors of performances, not texts, because the latter performed only auxiliary functions to the show. The lack of stage directions in the first dramas clearly indicates that a written text was not autonomous, which does not represent a ready-made depicted world, but only a sketchy score for the author-director, not the author-playwright. Only Aristotle contributes, around $335 \mathrm{BC}$, to a partial autonomy of text, by writing in the Poetics that tragedy can also affect without issue on stage and without the participation of the actors: tragic "action" is something concerned to text, not to performance (Aristotle's). But Greek classical dramas are actions, whose record is not a representation, but only a trace. Probably because of that Plato referred to the drama form, since - again - a text is not a representation of a philosophical action, but only its trace.

The performative, action-like and at the same time non-autonomous dimension of a philosophical text, including a dialogue text, will be the clearer, if we invoke the basic mode of operation of any literary texts in Plato's contemporary Greece. Reading scrolls written continuously required an interpretation on behalf of the reader: an inexperienced reader might have had substantial difficulties reading a text properly. In addition, the basic practice of reading in the ancient times was loud reading, what is more often shared reading, carried out in presence of others, in a social situation. Even St. Augustine expresses his surprise at seeing St. Ambrose reading in silence and solitude. Scroll was suited to selective, individualistic, analytic, focused on individual, compared with each other fragments, reading, to a lesser degree than a codex. A text, including the text of a philosophical dialogue, was perceived rather as a whole, similarly to a drama: as a performance. Focusing on individual theses as representations of certain truths was here very difficult: there was a focus on the whole conversation as an "event", because reading itself was a specific event indicating an activity in the social sphere, most likely among people sharing social ties or friends. It is not to be forgotten that the tools of punctuation, division into words and other forms of making a graphic text autonomous were only born in Alexandria, like philology as a science of a text understood as a self-contained object, independent from its voiced performance and from its particular, submerged in 
a social context, readings. The beginnings, in turn, of the approach to texts not as a memory aid, but external, independent media which are tools made to represent, not to recall specific content, are born, if David R. Olson is right, only in the era of advanced Middle Ages, when two theologians from St. Victor discover that texts can be read literally, with a simultaneous reconstruction of their historical context, and with paying attention to individual formulations seen as containers of the sense to be found in the text, not in the soul of the reader (Olson 1997).

Of course, the reconstruction of the method of reading and perceiving dialogues in the times of Plato is doomed to hypothesis and presumptions. However, there is a strong case for the fact that this reading was to a greater degree a community-created reading, done in a group people knowing each other well, and as such it could provoke an oral agon and philosophical debates, which were isomorphically adjacent to the world of text setting them in motion. Performing a dialogue did not move a reader, by means of the mechanism which was born with the modern novel, into the world depicted. At the same time, it could not provoke contemplation of individual theses as decontextualized entities containing philosophical truths: words of a dialogue are not yet reference tools. Performing a dialogue, most likely orally and among people interested in philosophy, provoked rather to new forms of engagement set into motion by a word read and delivered. Again: it was meant to be an incentive to take up a philosophical life, rather than logical analysis of single sentences.

\subsection{Augustine of Hippo and the modern era - from talking to people to talk of the mind}

The idea lying behind even St. Augustine's Cassiacum Dialogues is a similar way of thinking about dialogue. Also, in this case, we do not deal with fiction in the sense that the characters are real people. Its action takes place in his home in Cassiciacum, where he resides with his mother, friends and the rest of the family (son and brother), preparing for baptism and discussing. The credibility of philosophical research is testified here by real people: they are not textual constructs whose only function is to represent certain theses. Yet it is Augustine who made the text revolution by means of making partially autonomous the world depicted through a description of the context of the conversations. This is why, in The Happy life after an extensive dedication, he creates a new, from the point of view of Plato's dialogues, poetics, saying for example that "After a breakfast light enough not to in any way impede our thinking I invited all who were living together, not only that day, but every day, to meet at the bathing" (Augustine of Hippo 1984: 171). In short, Augustine structures a new character of dialogue: an author-character, and at the same time the narrator. This idea of a text is not only stage directions that make partially autonomous a script of the conversation. With such sentences, Augustine creates presentation tools for both the world external to the conversation and internal - the world of his own soul states accompanying the conversation: joy, sadness, uncertainty. Thus, he does, within the framework of dialogue, the same as what he also did in the Confessions, creating intellectual and also textual forms of subjectivity. He also 
creates and develops a new form which is an expression of the latter, namely the form of a dialogue as soliloqium - an internal conversation of the soul with itself. Philosophical agon is deprived of a political and social context, moving to the mind of an individual. Exchange of ideas does not require the interpersonal exchange, although traces the latter can be found in other dialogues by Augustine. Philosophy remains agon, it becomes, however, a private practice, cultivated in solitude, silence of the mind, which is beginning to be regarded as appropriate place for philosophical exploration. We deal here with the process that Arendt described in The Human Condition as "alienation from the earth", an earth which is a subject of joint conversation, and the apogee of which she placed in the era of western modernity.

This way of understanding dialogue is continued in modern times, leading to the collapse of not only the importance of the genre, but also the social practices considered worthy and appropriate for a philosopher. The Text begins to be regarded as a form of representation of certain philosophical theses, the meaning of which is independent of the practice of life, from interpersonal exchange and sociability understood as a form of celebration of the political and social significance of philosophy. Theses, in turn, are to an increasingly greater extent treated as inventions of a single mind, whose independence is strongly emphasized. A good example is Three dialogues between Hylas and Filonous by George Berkeley, which begins with an apology that one of its characters offers to another for interrupting his course of thoughts. The presence of a friend taking up a dispute is not treated as an inalienable part of philosophical proceedings. It only accelerates the course of thought, which would run essentially the same way even if no one interfered.

Apparently, these dialogues, in terms of the form, refer to Plato's dialogues, not Augustinian. Berkeley is not a character in those, and they do not contain any narrative part, a part presenting the context of the conversation. The similarity is, however, only apparent. Their characters have Greek names, which is a clear sign of them being fictional: they constitute only a literary construction. Berkeley deliberately creates characters not rooted in the existential context of the author. Truth or falsity of the spoken theses is not legitimized by persons having definite experience in life, persons linked to others by a network of common practices, values, and ties of friendship. On the contrary, the context of a person, time, place and signals are treated here as something negligent to the universality and timelessness of the taken diagnoses, something that does not strengthen their generality and reliability. Autonomisation of a discourse as a text, not as a philosophical conversation immersed in existential context, becomes an indicator of its objectivity. It is the complete opposite of Plato' thought. The names of the two interlocutors do not indicate any, even fictional, person either but the positions they present: Hylas is a voice of realism, defending the category of matter, Filonous supports idealism, defending the ontological primacy of the mind. Thus, the true characters of the dialogue become philosophical positions. The characters act only formally, presenting the right, according to Berkeley, theses (Filonous), and fighting off the competing theses, formulated by Hylas. A dialogue loses its negative character, characteristic for the early Plato's works, not so much concentrating on the process of joint investigation of the truth, becoming a treatise, scored for two voices, focused on a textual result in the form of representation and defense of certain philosophical theses. 
The crisis of the genre initiated by Plato, which is a symptom not only of attributing other functions to a philosophical text, related at least in part with media changes, but also with changes related to the social and political place of philosophy - was deepened by David Hume, who said directly about the inadequacy of the genre to the needs of the contemporary philosophy. Although the ancient thinkers - as he noted in the introduction to the Dialogues Concerning Natural Religion - presented their thoughts in this form, this way of writing "has been little practised in later ages, and has seldom succeeded in the hands of those who have attempted it" (Hume). Hume clearly indicates the reason for that: strict, methodical reasoning, necessary for fair practice of philosophy, requires the organization of a text around its theses and evidence. From this point of view, the dialogue seems to Hume, an unnecessary waste of time, a purely literary ornament, a victory of the form at the expense of the content, "to deliver a SYSTEM in conversation, scarcely appears natural" (Hume). Literary charms, according to Hume, are not able to make up for the loss of for the "order, brevity, and precision".

There is only one reason that allows to use this literary genre, which is invoked by the author of the Treatise on Human Nature: it is the ability to deceive the censorship, to whom it remains ambiguous which theses are advocated by the author, because in a dialogue the author is hiding behind the heterogeneity of the voices. Therefore, it is precisely this form which Hume chooses when approaching the problem of religion. The accusation of atheism, at the time of Hume, as is known, effectively hindered his career. It is, of course, a sign of not only of the role of religious institutions, against the primacy of which the Enlightenment advocated, but also of peculiar media conditions caused by the advanced culture of print. This culture, in addition to the multiplication of texts, their sources, and growing dominance of individualistic reading, the effects of which on interpretation are not subject to public scrutiny, creates mechanisms of state (censorship) and the church (the index of prohibited books) control of the content distributed via the printing press. These qualities of a dialogue will be used for quite a long time, also by writers of the twentieth century, including Stanislaw Lem, who directly invoked Berkeley's dialogue cited here, using not only its form in order to improve the presentation of issues related to the ethical implications of the development of cybernetics, but above all - tricking PRL censorship about the criticism, camouflaged in the text, of the socialist system.

In the modern era, using the form of a dialogue is regarded as an expression of popularization, and hence - a simplification of certain philosophical theses. Berkeley's dialogue is presupposed to popularize the thesis contained in the Treatise Concerning the Principles of Human Knowledge, which had not been understood properly. This compromise in order to popularize, according to philosophers, at the expense of the content, many authors use reluctantly. It leads to a modification of the genre, which is less and less like a lively conversation between living people, increasingly resembling, out of necessity, a written out for a few voices systematic treatise, whose nature has to be subordinated to the organization of the discursive content. Therefore, the mentioned before Hume's dialogue is divided into issues, accordingly to the topics tackled in the conversation: the course of the discussion is subjected to a strictly textual super organization, which moves linearly between successive problematic 'points'. This technique will be 
developed to the extreme in the New Essays on Human Understanding by Gottfried Leibniz. This work is devoted, as is known, to criticism of the works of John Locke. This is performed by Leibniz point by point with dividing the conversation into individual chapters, which are, in terms of their structure, closer to a treatise.

The protagonists of New Essays, as in Berkeley's and Hume's works, are fictional characters named in Greek. This is clearly to signal their distance to the author's existential contexts and at the same time timelessness of the issues that are being considered. Lebniz doesn't try to imitate a conversation: the disquisition never deviates from the thematic agenda imposed by the systematic structure of the chapters. Hence, the interlocutors announce: "We shall discuss first the origin of ideas or notions (Book I), then the different sorts of ideas (Book II) and the words that serve to express them (Book III), and then finally the knowledge and truths that result from them (Book IV)" (Leibniz 1996: 16). The world of the experience of those characters is an extremely textual one, like the language they speak, which is a specialist one. It is associated with highly advanced literacy, which both on the lexical and grammatical basis tries, as much as possible, to break off with everyday language. We are dealing here with the process, to which Michel de Certeau devoted lot of attention in his essays, and to which he referred by speaking of the attempt, characteristic of modernity, to constitute an artificial language of science, which would rely on a prior "removing" everyday language. As de Certeau said: "The Mastery of language guarantees and isolates a new power, "bourgeois" power, that of making history and fabricating languages. This power, which is essentially scriptural, challenges not only the privilege of "birth", that is, of the aristocracy, but also defines the code governing socioeconomic promotion and dominates, regulates or selects according to its norms all those who do not possess this mastery of language" (de Certeau 1984: 139).

A strict, made in the modern age, the division between the spoken colloquial language (the mythologized, condemned or fetishized voice of the people), and the artificial, written languages of science is something that, according to de Certeau, has visible socio-political repercussions. It is precisely for this reason that in dialogues of modern age the language of science and philosophy breaks off with the colloquiality of speech: in this age probably only Berkeley trusts the colloquial language more than the philosophical one, regardless of the skillfulness with which he used the latter, just as later Wittgenstein does, treating the language of philosophers as a source of mistakes. No wonder that even Nietzsche, formulating in On the Uses and Abuses of history for life a series of bitter theses on the academic, subordinated to the institutions of power, philosophy, makes use of the poetics of the genres classified as common ones, such as a newspaper article. Though, of course, he does it in an ironic way: the press is an opinion resource to a modern man, yet an opinion itself, contrary to Plato, should be, in his view, appreciated. He also breaks off with the philosophical terminology, which governs contemporary, German universities, and appeals to the language of literature as of what science has little in common with: it is no coincidence that the authorities invoked in this work are Schiller, Goethe and Shakespeare. It is no coincidence that Nietzsche plays with different, originally spoken genres either. The latter include a fairy tale, from which he begins the famous text On Truth and Lies in a Nonmoral Sense: "Once upon a time, in some out 
of the way corner of that universe which is dispersed into numberless twinkling solar systems, there was a star upon which clever beasts invented knowing" (Nietzsche 1976).

Let's return to Leibniz. The argument developed in New Essays On Human Understanding is, in relation to the previously mentioned works, extremely non-agonic: no elaborated counter-arguments interfere with the linear course of the argument. Equally symptomatic is the relationship linking the characters of the dialogue, it is the farthest one from the familiarity between Plato's characters: Teophilus and Philalethes have nothing in common but an interest in the topic of conversation. Critical distance, as an ideal providing patronage to the modern philosophy, indicated by mutual courtesy expressed by the form of "Mister" is considered to be appropriate for professional communication between people who share a common field. Friendship or any other extra-academic, not oriented to a specific discipline, social bonds are considered something that interferes with this communication.

\section{Two models of communication and the history of philosophical texts}

How to treat the path, outlined here, of the changes of the dialogue as a genre, and consequently the changes in the understanding of philosophy? In this article, I suggest to see it as a result of certain media and social change, whose complexity is still to be revealed. It is the developed culture of printing which strives for the semantic autonomy of a text. Texts, increasingly meant to not only to lonely, but also individualistic reading, are equipped with the signals of its illocutionary force. For a text, in the absence of the author and an institution ensuring its proper interpretation, has to speak for itself. At the same time, it begins to be treated not as a memory support, but as an independent means of conveying a content, a decontextualized message being, according to its author's intention, a representation of super-textual truths. Of course, one of the aims of this article was to show that an analysis of a text, like Plato's texts, performed with interpretation tools associated with the modern concept of the text is a presentation mistake. It is, in fact, identical to an ahistorical way of understanding the philosophical discourse as performing always and everywhere the same functions of reference tools intended for an individual reader and treated as a form of representation of theses, whose truthfulness can be later discussed, mainly by text practices. A mistake of the same kind is the qualification of the language of Plato's dialogues as not yet quite sophisticated and precise, as not being in compliance with the rules of logic as the art of proper formulation of sentences and relations between them.

Obviously, the changes being analyzed here are in no way to be considered only as derived solely from the domination of the print medium and the related transformation of ways of dealing with texts. It is not to be forgotten that one of the essential factors that determined the transformation of philosophy as a cultural institution and the ways of understanding its texts was the development of modern individualism and the birth of the individual. The relationship of these processes to the print - contrary to the popular views expressed, among others, by Marshall McLuhan, who suggested that the individual has been created the printing press - are not easy to grasp and certainly have not 
had an only one cause. And yet it is impossible to ignore the fact that in the common beliefs of modernity a philosopher is a person known primarily for writing and interpreting specialist texts, and not from a philosophical way of life as a process which is not confined to, oriented at literary practices of different kinds, intellectual activities. This was deplorable, perhaps most of all, for Nietzsche.

One of the ways of describing the transformations of western philosophy, which has not yet been consistently implemented is the description of its history with the category of gradual, progressive textualization. This means that two communication models analyzed by Ives Winkin, the orchestral and the telegraphic, the first being associated with perceiving communication as the act of interpersonal, linguistic and non-linguistic communion and the second, with perceiving it as a linear transfer of information from one mind to another, both of which are essentially unintelligible for each other, have their historical roots, especially the media background (Winkin 1996; Kulczycki 2015). The first is embedded in the alive word and in oral communication, rooted in an existential context and in living interaction between people, who generate activities and social ties. The second, is conditioned by the primacy of the printed word and quiet, solitary reading, which cuts out existential contexts, thus making a message autonomous as a language and graphic message, which is to be perceived in a linear and visual way, and isolating it from any direct social exchange. Both of these models are reflected well in philosophical texts. The dominance of the latter makes one capable of understanding why the philosophical dialogue as a remain of the conversation being both an existential and philosophical practice, has undergone, in the modern age, a sharp crisis.

Translation by Paweł Kosiorek

\section{References}

Arendt, Hannah. 1977. Life of the Mind: Thinking. San Diego, New York, London: Harcourt.

Arendt, Hannah. 2005. Socrates. In Kohn, Jerome (ed.), The Promise of Politics. New York: Schocken Books. Augustine of Hippo. 1984. Selected Writings, ed. M.T. Clark. New York: Paulist Press.

Bakhtin, Mikhail M. 1968. Rabelais and His World, transl. Hélène Iswolsky. Cambridge: MIT Press.

Bakhtin, Mikhail M. 1986. Speech Genres and Other Late Essays, transl. Vern W. McGee. Austin: University of Texas Press.

Bauman, Richard. 1986. Story, Performance, and Event: Contextual Studies of Oral Narrative. Cambridge: Cambridge University Press.

Bauman, Richard \& Briggs, Charles. 1992. Genre, Intertextuality and Social Power. Journal of Linguistic Anthropology 2(2). 131-172.

Berkeley, George. 1998. Three dialogues between Hylas and Filonous. Oxford: Oxford University Press.

Cassirer, Ernst. 1972. Essay on Man: An Introduction to a Philosophy of Human Culture. Yale University Press.

Certeau de, Michel. 1984. The Practice of Everyday Life, transl. S. Rendall. Berkeley, London: University of California Press.

Descartes, Rene. 2008. Discourse on the Method of Rightly Conducting one's Reason and Seeking Truth in the Sciences, transl. Ian Maclean. Oxford: Oxford University Press.

Foucault, Michel. 2005. The Hermeneutics of the Subject. New York: Palgrave Mcmillan.

Godlewski, Grzegorz. 2015. Anthropology of the Word. The Stepsister of Linquistic Anthropology. Anthropological Journal of European Cultures 24(1). 
Godlewski, G. \& Mencwel, A. \& Rodak, P. \& Sulima R. (eds). 2003. Antropologia słowa. Zagadnienia $i$ wybór tekstów. Warszawa: Wydawnictwa Uniwersytetu Warszawskiego.

Guthrie, William K.C. 1971. Socrates. London: Cambridge University Press.

Hadot, Pierre. 1995. Philosophy as a Way of Life: Spiritual Exercises from Socrates to Foucault, Boston, Oxford: Willey-Blackwell.

Hanks, William F. 1987. Discourse Genres in a Theory of Practice. American Ethnologist 14(4). 668-692.

Harris, Roy. 2009. Rationality and the Literate Mind. New York, London: Routledge.

Hume, David. 2008. Dialogues Concerning Natural Religion. Oxford: Oxford University Press.

Karpowicz, Agnieszka. 2014. Poławianie gatunków. In Godlewski, G. \& Karpowicz, A. \& Rakoczy, M. \& Rodak, P. (eds.), Od aforyzmu do zinu. Gatunki twórczości słownej. Warszawa: Wydawnictwa Uniwersytetu Warszawskiego.

Kulczycki, Emanuel. 2015. Dwa aspekty komunikacji. Założenia komunikologii historycznej. Poznań: Wydawnictwo Naukowe UAM.

Leibniz, Gottfried. 1996. New Essays on Human Understanding, transl. P. Remnant, J. Bennett. London: Cambridge University Press.

Majewski, Paweł. 2013. Pismo, tekst, literatura. Praktyki piśmienne starożytnych Greków i matryca pamięci kulturowej Europejczyków. Warszawa: Wydawnictwo Uniwersytetu Warszawskiego.

Morawski, Piotr. 2014. Dramat. In Godlewski, G. \& Karpowicz, A. \& Rakoczy, M. \& Rodak, P. (eds.), Od aforyzmu do zinu. Gatunki twórczości słownej. Warszawa: Wydawnictwa Uniwersytetu Warszawskiego.

Nietzsche, Friedrich. 1976. On Truth and Lies in a Nonmoral Sense, transl. W. Kauffmann. Viking Press.

Nightingale, Andrea Wilson. 2004. Spectacles of Truth in Classical Greek Philosophy. Theoria in its Cultural Context. Cambridge University Press.

Olson, David R. 1996. World on Paper. Conceptual and Cognitive Implications of Writing and Reading. New York: Cambridge University Press.

Ong, Walter J. 1982. Orality and Literacy. Technologizing of the Word. London: Psychology Press.

Plato. 1997. Plato: Complete Works, ed. by John M. Cooper, Indianapolis: Hackett Publishing.

Rakoczy, Marta. 2014. Dialog filozoficzny, traktat filozoficzny. In Godlewski, G. \& Karpowicz, A. \& Rakoczy, M. \& Rodak, P. (eds.), Od aforyzmu do zinu. Gatunki twórczości słownej. Warszawa: Wydawnictwa Uniwersytetu Warszawskiego.

Wendland, Michał (ed). 2015. Historia idei komunikacji. Poznań: Wydawnictwo Naukowe UAM.

Winkin, Ives. 1996. Anthropologie de la communication: de la théorie au terrain. Paris, Bruxelles: De Boeck Université. 